\title{
Effect of Composite Culture of Azotobacter and Phosphate Solubulizing Bacteria on in vitro Propagation of Musa acuminate (Banana)
}

\author{
Eurendra Kumar ${ }^{1}$, L. S. Verma ${ }^{2}$, D. Dash ${ }^{1}$ and S. B. Gupta ${ }^{1}$ \\ ${ }^{1}$ Department of Agricultural Microbiology, ${ }^{2}$ Department of Floriculture and Landscape \\ Architecture, College of Agriculture, IndiraGandhi Krishi Vishwavidyalaya, Raipur 492012 \\ (Chhattisgarh), India \\ *Corresponding author
}

\begin{abstract}
A B S T R A C T
The present study was conducted to assess the effect of composite culture of Azotobacter and Phosphate solubulizing bacteria with different combinations of organic, inorganic fertilizations on growth performance of in vitro propagated Banana, cv. Grand Naine. The in vitro rooted plantlets were hardened and acclimatized by using different treatments (five treatments comprising of inoculation of composite culture, vermicompost and Inorganic fertilization) carried out in CRD replicated four times. Propagation studies on primary hardening showed cocopeat was the best medium for primary hardening in terms of percentage survival of plantlets $(100.00 \%)$. Plantlets showed significantly highest height $(9.50 \mathrm{~cm})$, leaf number $(2.80$ per plantlet), girth $(4.50 \mathrm{~mm})$ when inoculation was given along with $25 \%$ NPK (organic) $+75 \%$ NPK (inorganic) in primary hardening. Similarly during secondary hardening, inoculation $+25 \%$ NPK (organic) $+75 \%$ NPK (inorganic) recorded best results in terms of plantlet height $(20.45 \mathrm{~cm})$, plantlet diameter $(11.60 \mathrm{~cm})$ no. of leaves $(5.25)$, length of primary roots per plantlet $(12.32 \mathrm{~cm})$. Maximum survival during secondary hardening $(100.00 \%)$ with composite culture inoculation whereas in other treatments survival percentage ranged from $87.5-93.5 \%$. Nitrogen uptake by banana significantly increased from 9.17 at control to $28.21 \mathrm{mg}$ per plantlet at inoculation + $25 \%$ NPK (organic) $+75 \%$ NPK (inorganic). For hardening and acclimatization of in vitro propagated banana, cv Grand Naine, composite culture $+25 \%$ NPK (organic) $+75 \%$ NPK (inorganic) showed overall superiority being the best treatment.
\end{abstract}

\section{Introduction}

Banana is known for its antiquity and is interwoven with Indian heritage and culture. In India, it is the second largest growing fruit crop next to mango and the leading producer in the world contributes more than $20 \%$ of global production. Total production of
Banana in Chhattisgarh is 0.4 metric tons from an area of 0.01 million hectare forming 22 per cent of the total fruit production in the state. It is a heavy consumer of nutrients and requires large quantities of nutrients for its growth, development and yield (Hazarika and Ansari, 2010). The requirements of these nutrients by inorganic fertilizers, results in 
extreme situations for the soil, crop and climate involved. The soil has lost its biological dynamic owing to repeated and indiscriminate use of chemical fertilizer; also these have some deleterious effects on fruit quality besides adverse effects on soil, water and environmental conditions (Dutta et al., 2010).

On the other hand, organic and microbial sources of nutrients have advantage of consistent and slow release of nutrients, maintaining ideal $\mathrm{C}$ : $\mathrm{N}$ ratio, improvement in water holding capacity and microbial biomass of soil profile, without having any adverse residual effects (Yadav, 2010). Biofertilizers are the living organisms that enrich the quality of soil which have an ability of mobilizing the important elements from non useable to useable form through chemical processes and known to increase yield (Alarcón et al., 2002). Apart from this, fruits often eaten raw are more vulnerable to contamination with chemicals due to their residual toxicity as compared to cereals and pulses. Biofertilizers were mainly used for field crops but now-a-days their potential can be seen to be fully exploited for fruit crops also like papaya (Sukhade et al., 1995) and banana (Gogoi et al., 2004). The contribution of beneficial microbes like Azotobacter, PSB in increasing the growth, yield and in reducing the fertilizer requirement have been brought out by few workers in fruit crops. However, very little work has been done on the use of biofetilizers in banana. However large scale plantation by this technology is hindered by high mortality experienced by micropropagated plantlets when transferred to ex vitro conditions, as during in vitro conditions, plantlets grow under special conditions, microshoots, upon transfer to ex vitro conditions are exposed to abiotic stress and biotic stress conditions. Improper hardening leads to the failure of whole technology. Success in hardening is a must for its survival (Radheshyam and Subramani, 2008). Hence, the present investigation is very important and opts for crops like banana to evaluate inoculation effect in primary and secondary hardening of tissue culture technology. With these backgrounds, the present study was undertaken to assess the application of organic fertilizer and biofertilizer for acclimatization of in vitro propagated banana plantlets. The objective was to evaluate the suitable combination of inorganic, organic and biofertilizers for tissue cultured banana to increase survival, growth of banana plants.

\section{Materials and Methods}

Experiments were conducted in the Plant tissue culture Laboratory, Indira Gandhi Agricultural University, Raipur (Chhattisgarh) during 2016-2017 with banana (Musa spp.cv: Grand Naine). In vitro rooted plantlets collected from Plant tissue culture lab, IGKV, Raipur were removed from the culture bottles and washed with water. Then these were subjected to different hardening treatments for getting maximum growth and survival.

\section{Primary hardening}

They were given a dip in composite culture of Azotobacter and Phosphate solubulizing bacteria solution for fifteen minutes and transferred to individual micropots in a protray containing media as cocopeat and placed in polytunnel located in shade house for five weeks. These were covered with polythene. The temperature ranged between 25 to $27^{\circ} \mathrm{C}$ and the relative humidity was maintained between 80 to 90 per cent inside the polytunnels (Jarret, 1986 and Wong, 1986). The experiment was arranged in completely randomized design with four replications, each replicate consisted of four micropot/ four banana plantlets. After 5 
weeks, data on growth parameters like percentage survival, mean plantlet height, mean plantlet diameter, mean no. of leaves were recorded and the data were analyzed statistically.

\section{Secondary hardening}

Primary hardened plantlets were transferred from micropots to polybags (size 4"x 6") containing substrate made up of mixtures of soil +sand+ vermicompost in 3:1:1 ratio treated with fungicide solution $\mathrm{CuSO}_{4}+$ bavistin+M45. Composite culture was applied as soil treatment to polybags as per treatments description before transfer of banana plantlets. These were covered with polythene sheet for 10 to 15 days initially and later on the polythene sheet was removed. The plantlets were maintained for 02 months inside a net house where the temperature ranged between 25 to $30{ }^{\circ} \mathrm{C}$ and relative humidity between 60 to 70 per cent (Jarret, 1986 and Wong, 1986). The experiment was arranged in completely randomized design (CRD) with four replications; each replicate consisted of four polybags containing. Data on growth parameters like percentage survival, mean plantlet height, mean plantlet diameter, mean no. of leaves were recorded twice at the end of each month. Root length, biomass accumulation, $\mathrm{N}$ content in shoot were recorded after two months, Nitrogen content in shoot was determined by Kjeldahal method (Jackson, 1958) and the data were analyzed statistically.

Composite culture for inoculation of banana plantlet consists of promising Azotobacter isolate and PSB isolate (obtained from Microbiology repository of Department of Agricultural Microbiology, CoA). Gram reaction and colony characterization of Azotobacter and PSB isolate were studied in Jenson's medium and Pikovskaya's media respectively of $\mathrm{pH}$ (7.0) and temperature $\left(28^{\circ} \mathrm{C}\right)$. Organic manure through vermicompost. RDF as 300: 100: $300 \mathrm{~g} \mathrm{NPK} \mathrm{/}$ plant. Inorganic fertilizer Nitrogen, Phosphorous and Potassium were given through Urea, SSP and MOP in liquid form with distilled water as per the treatment.

Data recorded for different parameters were subjected to completely randomized design (CRD). Statistical analysis based on mean values per treatment was made using analysis of variance technique of CRD (Panse and Sukhatme, 1978).

\section{Results and Discussion}

\section{Colony morphology and Gram staining}

Azotobacter isolates and PSB isolate were revived by inoculating in Jensen's medium and Pikovskaya's medium respectively of $\mathrm{pH}$ (7.0) and temperature $\left(28^{\circ} \mathrm{C}\right)$ for preparation of inoculum for banana plantlet. As per cultural and colony characteristics, Azotobacter isolate in Jensen's medium showed gummy, round and convex, colony with entire margin, whitish in colour and Gram negative in reaction. Colonies of PSB isolate in Pikovskaya's medium were found to be round and yellowish in colour, showing clearing zone. The isolate was Gram negative and belonged to Pseudomonas genera based on staining, morphological and cultural tests according to Bergey's Manual of Systematic Bacteriology. This work is in line with Krishnaveni (2010). Pseudomonas sp. act as efficient solubilizers of Phosphorous is in line with the findings of Komy (2005) also observed similar colony characteristics in PSB.

The banana plantlets from culture vessels in tissue culture laboratory, IGKV were taken. Effect of the composite culture of Azotobacter and PSB inoculants were evaluated on the growth performances of in vitro propagated 
banana during primary and secondary hardening. Success in hardening is a must for its survival (Radheshyam and Subramani, 2008). Hardening the in vitro raised plantlets; so as to make them adapted to the natural environment is a critical process due to their anatomical and physiological peculiarities (Hazarika, 2003). Therefore Primary and Secondary hardening is an integral and vital activity of the whole process of tissue culture technology.

\section{Effect of inoculation on in vitro propagated banana plantlets during primary hardening}

In the present study cocopeat was taken as potting media in primary hardening and was found superior in terms of percentage survival of plantlets $(100 \%)$ during primary hardening. This may be due to better aeration, water holding and nutrient supplying capacity of cocopeat. Further inoculation of composite culture involving Azotobacter and PSB significantly influenced the growth of banana plantlets (cv.Grand Nain). Results on morphological growth parameters of primary hardened banana plantlets treated with different treatments are presented in (Table 2). Experimental view of primary hardening was shown in Fig.1. As per the growth of primary hardened banana plantlets (cv.Grand Nain) , significantly maximum height (9.50 $\mathrm{cm})$, number of leaves (2.8), plantlet diameter $(4.50 \mathrm{~mm})$, was observed when inoculated with composite culture along with $25 \%$ NPK (organic) $+75 \%$ NPK ( inorganic) which was at par with inoculation along with $75 \%$ NPK ( inorganic). Significantly highest plant height $(10 \mathrm{~cm})$ was found in $\mathrm{T} 5$ followed by $\mathrm{T} 4$ $(9.45 \mathrm{~cm})$. Probably cocopeat, organic manures and inoculation treatments might have helped in improving physical and chemical properties of the growing media, consequently resulted in better growth of banana plantlets (Hazarika, 2003 and Anbazhagan et al., 2014). Significantly highest basal girth of primary hardened banana plantlets $(4.50 \mathrm{~mm})$ was found in $\mathrm{T} 5$ and T4. However banana plantlets showed significant variation in plant girth ranging from 3.41 to $4.50 \mathrm{~mm}$ during primary hardening. The number of leaves plant ${ }^{-1}$ increased significantly from 2.1 to 2.8 per plantlet with inoculation treatments. Excessive water loss from plantlets was prevented by giving various inoculation treatments. These treatments were found to influence greatly the survival and growth of plantlets.

\section{Effect of inoculation on banana plantlets during secondary hardening}

Primary hardened plantlets were shifted to polybags in net house for secondary hardening. Potting mixture containing soil, sand and Vermicompost (3: 1: 1). The data pertaining to the influence of different treatments on survival and growth of plantlets were presented in Table 3. 100 per cent survival was obtained in the inoculated plantlets which was superior to all other treatment. At T3 the percent survival was 93.5 and minimum survival percentage was recorded in T1 and T2, i.e., 87.5\%. Similar results were reported by Jasari et al., (1999). All plantlets was kept covered with polythene sheet and kept in control condition in net house (Fig. 2). Covering the plantlets with polythene sheet in groups and keeping them in culture room was also found to be suitable, recording increasing per cent survival. The method of covering the new transferred plantlets for initial period and subsequently removing the cover is a gradual process, was successfully adapted by number of workers for hardening the plantlets (Jasrai et al., 1999) and (Vasane and Kothari, 2008). According to them plantlets develop their stomatal control mechanism during this period.

Shoot length increased by 1.87 and 1.78 times over control with inoculation alone $\mathrm{T} 4$ and 
along with $25 \%$ organic manure (T5) respectively after secondary hardening. In Inorganic Fertilization, shoot length was found $(14.47 \mathrm{~cm})$ in $\mathrm{T} 2$ while in control (T1) it was $11.00 \mathrm{~cm}$. Number leaves, Plant girth of banana plants showed significant effect in inoculated treatments with composite culture of Azotobacter and PSB alone and along with $25 \%$ organic manure $+75 \%$ inorganic fertilizer (T5), followed by inoculation +75 $\%$ inorganic fertilizer (T4) over other treatments. Banana plantlets showed significantly different plant girth ranging from 7.42 to $11.60 \mathrm{~mm}$ at different stages of growth during secondary hardening being significantly highest in $\mathrm{T} 5$ followed by $\mathrm{T} 4$ $(11.12 \mathrm{~mm})$. The girth of plants at primary and secondary decapitation stage also had a significant role in the production of next generation buds. Highest number of leaves/plant (5.80) was found in T5and T4. Composite culture inoculation significantly influenced the root growth of banana plantlets increasing root length by 1.74 times over control. Significantly highest primary root length $(12.32 \mathrm{~cm})$ was found in T5 followed by $12.00 \mathrm{~cm}$ in $\mathrm{T} 4$. The data on root length did not show significant difference between $\mathrm{T} 2$ and $\mathrm{T} 3$.

Table.1 Treatment combinations used in macropropagation of banana

\begin{tabular}{|r|l|}
\hline T1 & Control \\
\hline T2 & 100\% RDF \\
\hline T3 & $50 \%$ NPK through Organic manure $+50 \%$ NPK (inorganic ) \\
\hline T4 & Inoculation of composite culture $+75 \%$ NPK(inorganic) \\
\hline T5 & Inoculation of composite culture $+25 \%$ NPK (organic) $+75 \%$ NPK (inorganic) \\
\hline
\end{tabular}

Table.2 Effect of inoculation on banana plantlets during primary hardening

\begin{tabular}{|l|l|l|l|l|}
\hline Treatments & $\begin{array}{l}\text { Plantlet } \\
\text { height }(\mathbf{c m})\end{array}$ & $\begin{array}{l}\text { Plantlet girth } \\
(\mathbf{m m})\end{array}$ & $\begin{array}{l}\text { No. of leaves } \\
\text { per plantlet }\end{array}$ & $\begin{array}{l}\text { Per } \\
\text { Survival (\%) }\end{array}$ \\
\hline $\mathbf{T}_{\mathbf{1}}$ & 7.18 & 3.41 & 2.1 & 100 \\
\hline $\mathbf{T}_{\mathbf{2}}$ & 9.42 & 3.85 & 2.6 & 100 \\
\hline $\mathbf{T}_{\mathbf{3}}$ & $\mathbf{7 . 7 4}$ & 3.67 & 2.3 & 100 \\
\hline $\mathbf{T}_{\mathbf{4}}$ & $\mathbf{9 . 4 5}$ & 4.50 & 2.8 & 100 \\
\hline $\mathbf{T}_{\mathbf{5}}$ & 9.50 & 4.50 & 2.8 & 100 \\
\hline $\mathrm{SEm}( \pm)$ & 0.241 & 0.146 & 0.128 & - \\
\hline $\mathrm{CD}(\mathbf{P}=\mathbf{0 . 0 5})$ & 0.734 & 0.445 & 0.390 & - \\
\hline
\end{tabular}

T1 - Control, T2 - $100 \%$ RDF (300:100:300 g NPK per plant), T3 - 50\% NPK through Organic manure + $50 \%$ NPK(inorganic), T4 - inoculation of composite culture $+75 \%$ NPK (inorganic), T5 - Inoculation of composite culture $+25 \%$ NPK (organic) $+75 \%$ NPK (inorganic) 
Table.3 Effect of inoculation on growth parameters of in vitro propagated banana plantlets during secondary hardening

\begin{tabular}{|c|c|c|c|c|c|c|}
\hline \multirow[t]{2}{*}{ Treatments } & \multicolumn{2}{|c|}{ Plantlet height (cm) } & \multicolumn{2}{|c|}{ Plantlet girth (mm) } & \multicolumn{2}{|c|}{$\begin{array}{l}\text { No. of leaves per } \\
\text { plantlet }\end{array}$} \\
\hline & $\begin{array}{l}\text { At } 1 \\
\text { month }\end{array}$ & At 2 month & $\begin{array}{l}\text { At } 1 \\
\text { month }\end{array}$ & $\begin{array}{ll}\text { At } & 2 \\
\text { month } & \end{array}$ & $\begin{array}{ll}\text { At } & 1 \\
\text { month }\end{array}$ & $\begin{array}{lr}\text { At } & 2 \\
\text { month } & \end{array}$ \\
\hline $\begin{array}{l}T_{1} \\
\text { Control }\end{array}$ & 10.25 & 11.00 & 7.42 & 8.91 & 3.51 & 3.82 \\
\hline $\begin{array}{l}\mathrm{T}_{2} \\
100 \% \mathrm{RDF}\end{array}$ & 13.75 & 14.47 & 8.64 & 9.57 & 4.25 & 4.51 \\
\hline $\begin{array}{l}\mathrm{T}_{3} \\
\mathbf{5 0} \% \text { NPK Organic + } \\
50 \% \text { NPK (inorganic) }\end{array}$ & 13.19 & 16.00 & 9.26 & 10.40 & 4.86 & 5.30 \\
\hline $\begin{array}{l}\mathrm{T}_{4} \\
\text { inoculation }+\mathbf{7 5 \%} \text { NPK } \\
\text { (inorganic) }\end{array}$ & 13.81 & 19.17 & 10.35 & 11.12 & 5.05 & 5.80 \\
\hline $\begin{array}{l}\mathrm{T}_{5} \\
\text { Inoculation }+25 \% \text { NPK } \\
\text { (organic) }+75 \% \text { NPK } \\
\text { (inorganic) }\end{array}$ & 14.14 & 20.45 & 10.64 & 11.60 & 5.25 & 5.80 \\
\hline $\operatorname{SEm}( \pm)$ & 0.254 & 0.328 & 0.176 & 0.194 & 0.194 & 0.144 \\
\hline $\mathrm{CD}(\mathrm{P}=\mathbf{0 . 0 5})$ & 0.772 & 0.997 & 0.537 & 0.589 & 0.591 & 0.438 \\
\hline
\end{tabular}

Table.4 Effect of inoculation on survival percentage, root length, biomass accumulation and shoot $\mathrm{N}$ content of banana plantlets after secondary hardening

\begin{tabular}{|c|c|c|c|c|c|}
\hline Treatments & $\begin{array}{l}\text { Per cent } \\
\text { Survival } \\
(\%)\end{array}$ & $\begin{array}{l}\text { Length of } \\
\text { primary } \\
\operatorname{root}(\mathrm{cm})\end{array}$ & $\begin{array}{l}\text { Shoot dry } \\
\text { weight } \\
\text { (g/plant) }\end{array}$ & $\begin{array}{c}\text { Shoot fresh } \\
\text { weight (g/ } \\
\text { plant) }\end{array}$ & $\begin{array}{l}\text { Nitrogen } \\
\text { accumulation } \\
\text { (mg } \\
\text { /plantlet) }\end{array}$ \\
\hline $\mathbf{T}_{1}$ Control & 87.5 & 5.20 & 0.74 & 4.27 & 9.17 \\
\hline $\mathrm{T}_{2} 100 \% \mathrm{RDF}$ & 87.5 & 10.45 & 1.18 & 9.85 & 16.28 \\
\hline $\begin{array}{l}\mathrm{T}_{3} 50 \% \text { NPK Organic }+50 \% \text { NPK } \\
\text { (inorganic) }\end{array}$ & 93.5 & 11.25 & 1.35 & 10.39 & 19.03 \\
\hline $\begin{array}{l}\mathbf{T}_{4} \text { inoculation } \\
\text { (inorganic) }\end{array}$ & 100 & 12.00 & 1.53 & 13.49 & 25.40 \\
\hline $\begin{array}{l}\mathrm{T}_{5} \text { Inoculation }+25 \% \quad \mathrm{NPK} \\
(\text { organic) }+75 \% \text { NPK (inorganic) }\end{array}$ & 100 & 12.32 & 1.64 & 14.01 & 28.21 \\
\hline $\operatorname{SEm}( \pm)$ & - & 0.263 & 0.050 & 0.448 & 0.579 \\
\hline $\mathrm{CD}(\mathrm{P}=\mathbf{0 . 0 5})$ & - & 0.800 & 0.152 & 1.364 & 1.761 \\
\hline
\end{tabular}




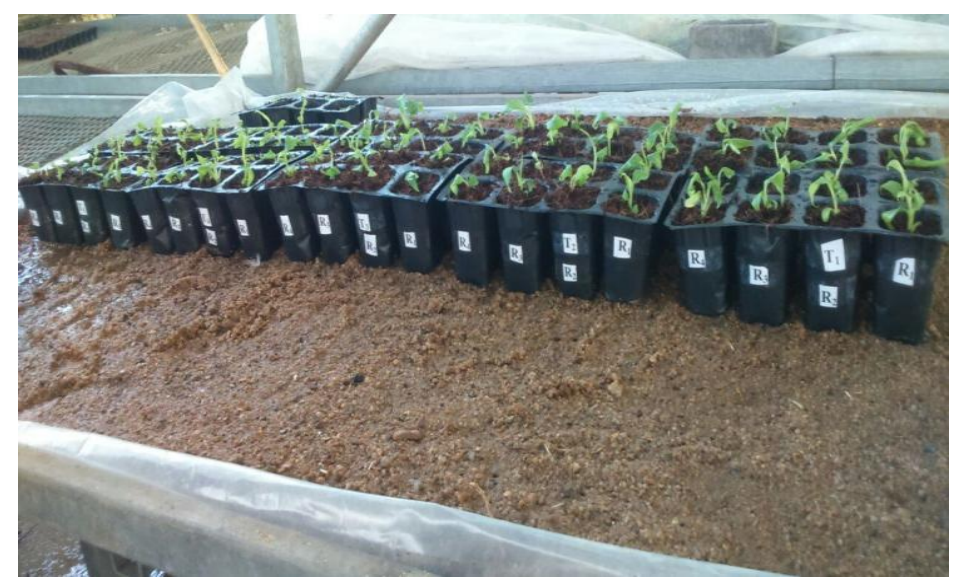

Fig.1 Transplantation of young banana plantlets from culture vessels

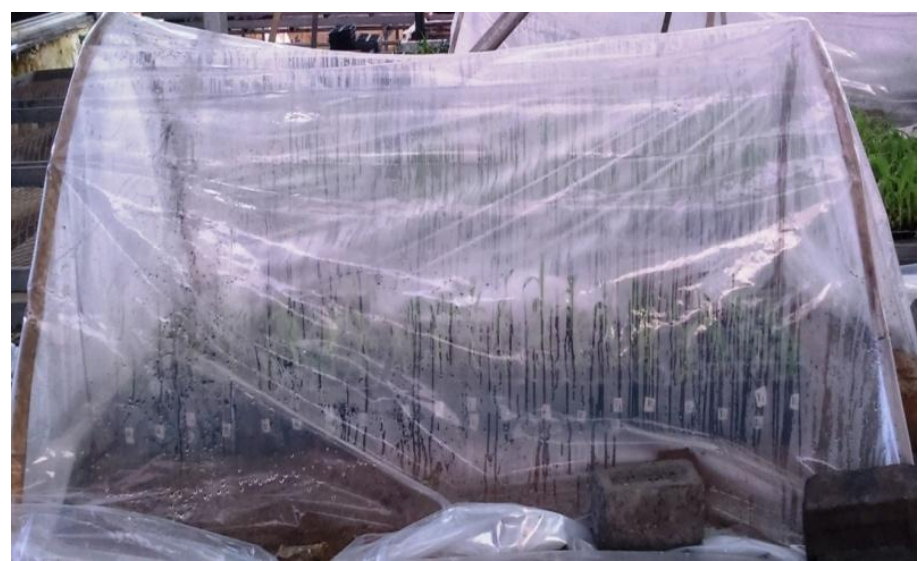

Fig.2 Acclimatization of banana plantlets: Covering the plantlets with polythene sheets

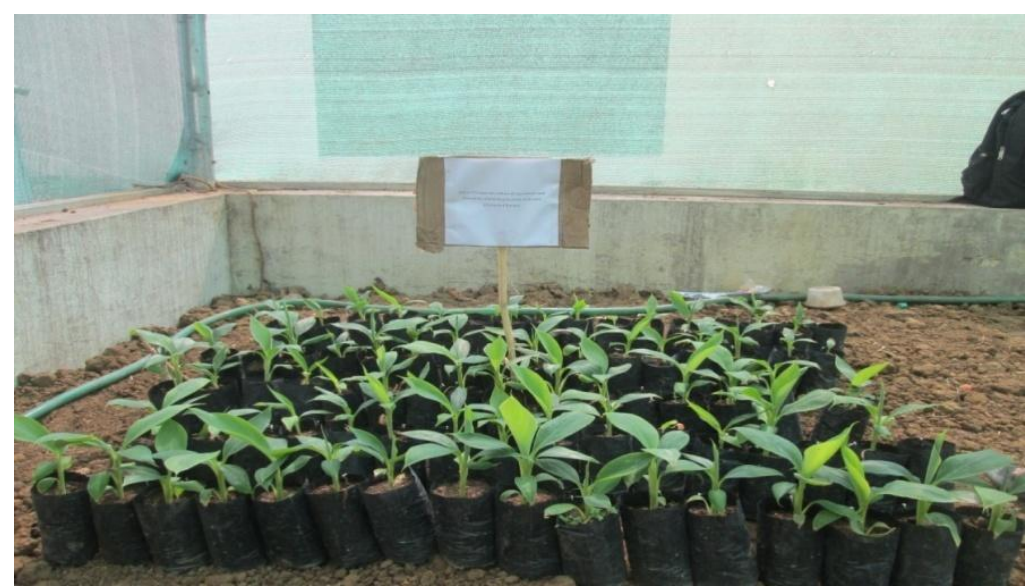

Fig.3 Transferring into nursery polypots in net house for secondary hardening. Plantlets established in potting mixtures 


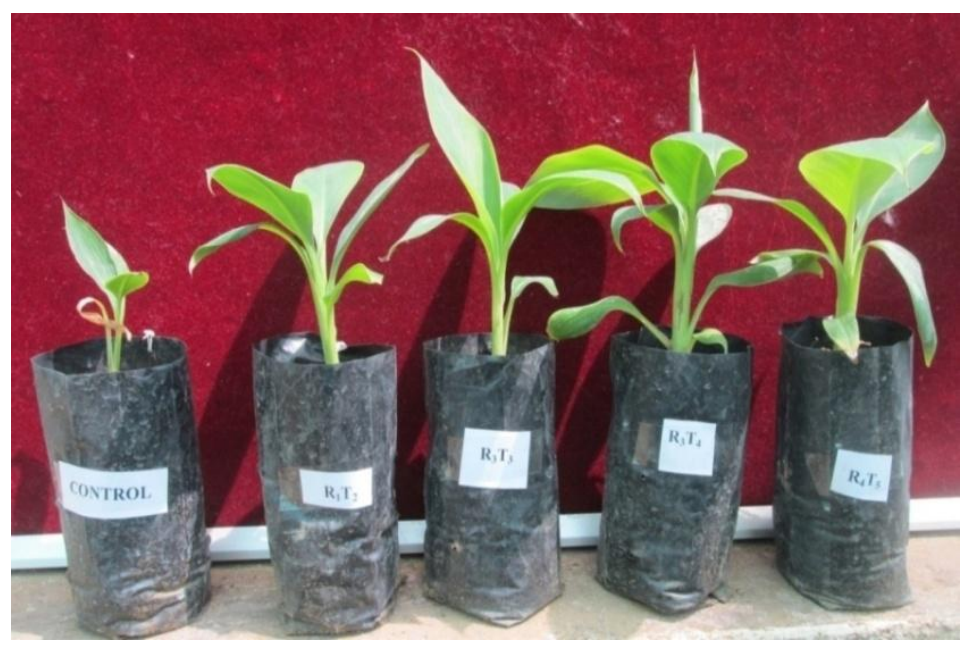

Fig.4 Well established secondary hardened banana plantlets in poly bags

Biomass accumulation in banana plantlets after secondary hardening

Fresh and dry Biomass accumulation in shoot of banana plantlet ranged from 4.27 to 14.01 $\mathrm{g} /$ seedling and 0.74 to $1.64 \mathrm{~g} /$ seedling at 2 months in secondary hardening respectively under different treatments table 4. 32.21\% increased in shoot dry biomass accumulation over $T_{1}$ control was found by banana plantlets at 2 months in secondary hardening in inoculation with Azoto + PSB $+25 \%$ organic $+75 \%$ inorganic $\left(\mathrm{T}_{5}\right)$. Composite culture inoculation with Azoto + PSB $+25 \%$ organic+ $75 \%$ inorganic fertilization $\left(\mathrm{T}_{5}\right)$, treatment produced significantly maximum shoot dry biomass of $1.64 \mathrm{~g} / \mathrm{seedling}$ against 1.18 and $0.74 \mathrm{~g} /$ seedling at $100 \% \mathrm{RDF}$ and control respectively.

\section{Nitrogen accumulation in banana plants}

Significantly highest N uptake $(28.21 \mathrm{mg} /$ plant) were observed in inoculated shoot with composite culture $+25 \%$ NPK (organic) + $75 \%$ NPK (inorganic) followed by $25.40 \mathrm{mg} /$ plant inoculation of composite culture $+75 \%$ NPK (inorganic) (Table 4). Similar trend in nutrient concentration was reported by Kaushik et al., (2003). The application of bio fertilizer also increased the uptake of nutrients, which enhanced the growth and development of seedling. The adequate supply of moisture, mineral, nutrients, ensure the better growth and development of plantlets. It is well established fact that inoculation of composite culture is better as compared to inorganic fertilization and control treatments. This can also be clearly seen in Fig. 4

The present findings showed that Inoculation of composite culture $+25 \%$ NPK (organic) + $75 \%$ NPK (inorganic) application along with was comparatively better for improving growth and development of banana plantlet as it influences other process such as nutrient transformation, uptake of trace element and plant hormones.

Results of present investigation are in close confirmation with the findings of Saxena (2010). This work is strongly supported by Krishnaveni et al., (2010). Data derived from the inoculated treatments showed better root system and survived better during the acclimatization stage. These results are in line with the earlier reports indicating that inoculants significantly improved banana nutrition. 
It is concluded that incorporation of additives like bio-fertilizers and vermicompost has not only promoted the growth and development, but also may enhance plantlets by reducing the post transplanting shock and enhancing the per cent survival in the field. . Giving Azotobacter and PSB inoculants in primary and secondary hardening of banana plantlets may produce quality planting material in banana.

\section{References}

Alarcón, A., Davies Jr, F. T., Egilla, J. N., Fox, T. C., Estrada-Luna, A. A., \& Ferrera-Cerrato, R. 2002. Short term effects of Glomus claroideum and Azospirillum brasilense on growth and root acid phosphatase activity of Carica papaya L. under phosphorus stress. Revista Latinoamericana de Microbiología, 44(1): 31-37.

Anbazhagan, M., Balachandranand, B. and Arumugam, K. 2014. In vitro propagation of Musa acuminata (Banana). J. Res. Plant Sci. 4(1): 26-29.

Dutta, P., Kundu, S., \& Chatterjee, S. 2010. Effect of Bio-Fertilizers on Homestead Fruit Production of Papaya cv. Ranchi. In II International Symposium on Papaya 85(1): 385-388.

Gogoi, D., U. Kotoky, and S. Hazarika. 2004. Effect of biofertilizers on productivity and soil characteristics in banana. Indian Journal of Horticulture 61: 354 356.

Hazarika, B. N. 2003. Acclimatization of tissue-cultured plants. Curr Sci. 85:1704-1712.

Hazarika, B.N. and Ansari, S. 2010. Effect of integrated nutrient management on growth and yield of banana cv. Jahaji. Indian J. Hort. 67: 270-273

Jarret, R. L. 1986. In vitro propagation and genetic conservation of bananas and plantains. In IBPGR Advising committee on and in vitro storage, report of the third meeting (Appendix) IbPGr, Rome, Italy. pp.12-14.

Jasrai, Y. T., Kannan, B. R., Remakanthan, A. and George, M. M. 1999. Ex vitro survival of in vitro derived banana plants without greenhouse facilities. Plant Tissue Culture. 9: 127-132.

Kaushik, J.C., Dabas, P and Kumar, R. 2003. Influence of Glomus mosseae, phosphorus and drought stress on the nodulation and nutrient content of Acacia nilotica and Dalbergia sissoo seedlings. Indian Jounral of Forestry, 26(1): 11-13

Komy, M.A.H. 2005.Co immobilization of Azospirillum lipoferum, Bacillus megaterium for Successful Phosphorus, Nitrogen Nutrition of Wheat Plants. Food Technol. Biotechnol., 43 (1): 1927.

Krishnaveni M.S. 2010. Studies on Phosphate Solubilizing Bacteria (PSB) in Rhizosphere and Non-Rhizosphere Soils in Different Varieties of Foxtail Millet (Setaria italica) International Journal of Agriculture and Food Science Technology Volume 1, Number 1, 23-39.

Panse, V.G. and Shukhatme, P.V. 1978. Statistical Methods for Agricultural Workers . Indian Council of Agricultural Research. New Delhi. Pp. 145-156.

Radheshyam, K. H. and Subramani, J. 2008. Hardening and acclimatization of banana tissue culture plantlets. In 4th international symposium on acclimatization and establishment of micropropagated plants, 8th -12 th, December, Bangalore, Abstracts, pp. 43

Saxena, J. 2010. Disease suppression and crop improvement in moong beans (Vigna radiate) through Pseudomonas and Burkholderia strains isolated from semi 
arid region of Rajasthan, India. BioControl, 55(6): 799-810.

Sukhada, M., Shivananda, T.N. and Iyenger, B.R.V. 1995. Uptake of 32P labelled superphosphate by endomycorrhizal papaya (Carica papaya cv. Coorg Honey Dew). Journal Nuclear of Agriculture 24(4): 30-31.

Vasane, S. R. and Kothari, R. M. 2008. An integrated approach to primary and secondary hardening of banana var. Grand Naine. Indian J. Biotechnology.
7: 240-245.

Wong WC. 1986. In vitro propagation of banana (Musa spp.): Initiation, proliferation and development of shoottip cultures on defined media. Plant Cell, Tissue and Organ Culture. 6, 159166.

Yadav, S. K., Prasad, R. and Khokhar, U. U. 2010. Optimization of integrated nutrient supply system for strawberry $\mathrm{cv}$. Chandler. Sci. Hort., 124(1): 62-66.

\section{How to cite this article:}

Eurendra Kumar, L. S. Verma, D. Dash and Gupta, S. B. 2020. Effect of Composite Culture of Azotobacter and Phosphate Solubulizing Bacteria on in vitro Propagation of Musa acuminate (Banana). Int.J.Curr.Microbiol.App.Sci. 9(05): 1691-1700.

doi: https://doi.org/10.20546/ijcmas.2020.905.190 